writers, and in the vast majority of cases the first species is taken by them as the type. In nearly every case where the A. O. U. Check List and the British Museum Catalogue differ in the selection of a type species for an ornithological genus, the adoption of the first species by the Americans will bring them into accord.

(c) That we have in the 'first species rule' a method that can lead to but one result and can be practised by any one, and by which the type of a genus can be ascertained at once by consulting one reference, instead of involving the examination of many works and the expenditure of much time and thought. WitMer StONe.

\section{Academy of Natural Sciences,} Philadelphia.

\section{GENERIC NAMES OF MERYCOIDODONTS.}

As there has been no recent thorough revision of the Merycoidodonts (Oreodonts auctorum), based upon an examination and comparison of all the types, there has been much confusion and error in the use of nearly all of the generic names. Many new forms have recently been discovered, and investigation has been greatly retarded by uncertainty as to where many of these should be placed. By the kindness of those who are in charge of the various museums which contain the types of the genera, the writer has had the opportunity of examining all of the older types, and he here gives his conclusions concerning the various names which have been used.

\section{Merycoidodon Leidy.}

Type Merycoidodon culbertsoni Leidy. Proceedings Academy Natural Sciences, Philadelphia, Vol. IV., 1848, p. 47, Plate.

Synonyms: Oreodon culbertsoni (Leidy), 0. priscum Leidy, Cotylops speciosa Leidy.

The type is a portion of the upper jaw with the last two molars, and a fragment of the mandible with all the lower molars. The outer cusps of the second upper molar, and the heel of the last lower molar are gone. The type was sent from the Bad Lands of Dakota by Mr. T. Culbertson and is now the property of the Academy of Natural Sciences in Philadelphia. The two specimens probably belong to the same individual, as the last molar in both jaws is in about the same stage of eruption. These molars, though fully formed, had not yet attained the level of the other teeth, but they are well exposed, so that their structure can be easily seen.

Dr. O. P. Hay (Science, Vol. IX., April 21, 1899, p. 593, and 'Catalogue of the Fossil Vertebrates of North America', p. 665) has reinstated the original name Merycoidodon in the place of Oreodon, which had come into universal use. He says that Merycoidodon clearly has priority over both Oreodon and Cotylops. There is a close similarity in the teeth of the Middle Oligocene Merycoidodonts, and it seemed best, at least until the type should be found and its identity with 'Oreodon' demonstrated, to use the commonly accepted name; but now, after having examined the type and compared it with various specimens of so-called Oreodon culbertsoni, I believe that the original name should be used for the following reasons:

1. The type specimen was fully described by Leidy and figures were published, which, though not clear enough, perhaps, to distinguish Merycoidodon from specimens of closely allied genera, leave no doubt as to the identity of the type specimen.

2. The name Cotylops was given to a young individual with the milk dentition. The type of Oreodon was the 'greater portion of a cranium' with teeth in a very much mutilated condition, sent to Dr. Leidy by Dr. Hiram Prout, of St. Louis. (Proceedings Academy Natural Sciences of Philadelphia, Vol. V., p. 237.)

3. This type appears to be lost, but Dr. Leidy, who was a careful observer, had the types of Merycoidodon, Oreodon and Cotylops all before him and he said that the true molars of Oreodon had exactly the same form and very nearly the same size as the posterior two molars of Merycoidodon. He afterwards concluded that these genera belonged to the same species.

4. So far as the present writer has observed there are differences, though not great, which separate Merycoidodon from nearly related 
genera, so that, as a rule, Merycoidodon can be distinguished by the teeth alone.

\section{Eucrotaphus Leidy.}

Proceedings Academy of Natural Sciences, Philadelphia, Vol. V., 1850, p. 90. Type Eucrotaphus jacksoni Leidy.

The type specimen is the posterior portion of a skull in the Academy of Natural Sciences in Philadelphia. According to the label it comes from near Fort Laramie, Wyoming, and was presented by Alexander Culbertson. The type specimen is distinguishable from Eporeodon by peculiarities in the basal portion of the skull; and, so far as I have observed, the more complete specimens with large bullæ from the region of the plains are different from those of Oregon; therefore it seems best at present to consider them as belonging to separate genera. In the type of Eucrotaphus the tympanic bulla is large and symmetrically rounded, the paroccipital process is intermediate between that of Merycoidodon and Eporedon, being more transverse and laterally expanded at the base than in the former and less than in the latter. There is no lamina of bones separating the pit for the tympanohyal from the stylomastoid foramen as in Merycoidodon. The external auditory meatus is trumpet-shaped and not greatly enlarged as in Eporeodon.

\section{Eporeodon Marsh.}

American Journal Science (3), IX., 1873, p. 249.

Type Eporeodon occidentalis Marsh.

A skull from John Day River, Oregon. Presented to the Yale Museum by Rev. Thomas Condon.

Marsh evidently failed to mark the type, but only one skull in the Condon collection corresponds to the type as Marsh designated it. The bullæ are inflated. The paroccipital processes are transverse and moderately expanded laterally and are not so prismatic behind the bulle as in Eucrotaphus. The two genera are readily distinguishable by the forms of the external portions of the tympanics. In Eporeodon the external auditory meatus occupies a large space between the postglenoid and paroccipital processes. There is a deep pit for the tympanohyal and it is so placed that it looks almost like an inner opening to the external meatus. There is no pit for the mastoid foramen. The outer portion of the external auditory meatus is expanded anteriorly into a wing in other specimens of Eporeodon, and I think it is also thus expanded in the type, though my notes do not state the fact. Most of the John Day skulls are flattened on top and the upper contour of the skull is nearly straight. This usually serves at a glance to separate Eporeodon from Eucrotaphus, but occasionally there is a skull from the John Day formation more like those of Eucrotaphus.

\section{Mesoreodon Scott.}

Type Mesoreodon chelonyx Scott, American - Naturalist, Vol. XXVII., 1893, p. 661.

The type, which is contained in the Princeton Museum, is a skull and mandible with a large portion of the skeleton. It was obtained in the lower Deep River (Fort Logan) beds in Smith River valley in Montana. The skull is still partially enclosed in a hard matrix, so that some of the characters, which distinguish the previously mentioned genera, can not be clearly made out in this specimen. The skull is rather high, not depressed vertically as in Eporeodon. The teeth are not high, but according to Scott the molars show 'an incipient tendency to hypsodontism.' The paroccipital processes are expanded laterally above, are prismatic below and are in contact with the tympanic bullæ anteriorly. The external and auditory meatus is long, straight, directed upward as well as outward and backward, and has anterior wings in contact with the postglenoid processes. It probably can be distinguished from Eporeodon by its larger size, higher skull, the different form of the squamosal processes of the zygoma, and the different form of the tympanics.

\section{Promerycocharens Douglass.}

Type Promerycochœrus superbus Leidy, American Journal of Science, January, 1901, p. 82.

From the upper John Day beds, Oregon. 
The type is the property of the Rev. Thomas Condon, who loaned it to the Yale Museum. It consists of the greater portion of a skull, from which the matrix has not been fully removed. The specimen was first described as Oreodon by Leidy, but was afterward assigned to the genus Merycochoerus by Bettany. After the discovery of more complete remains of Merycochorus it was seen by Matthew and Douglass that the specimens from the John Day were very different, and the latter gave them the name Promerycochœrus, making $P$. superbus the type. The skull is large and elongated. The upper contour is nearly straight, the squamosal portions of the zygomatic arches are enlarged. The occiput is not high, and the tympanic bullæ are large and elliptical.

Merycoidodon, Eucrotaphus, Eporeodon, Mesoreodon and Promerycochorus appear to be quite closely related, and, when more is known of them, it may be found difficult to generically differentiate some of them, yet it is undoubtedly better to keep them separate at present. Their near relationship seems to be confirmed by the characters of the feet and other portions of the skeleton. Merychyus, Ticholeptus and Merycochœrus are apparently more distantly related to the foregoing and to each other.

\section{Merychyus Leidy.}

Type Merychyus elegans Leidy. Proceedings Academy Natural Sciences, Philadelphia, 1858 , p. 24.

From the Miocene of the Niobrara Valley, Nebraska. The type consists of portions of maxillaries and a mandible with teeth, and is preserved in the Academy of Natural Sciences in Philadelphia. Size rather small, not larger than Eporeodon. Premolar shorter than the molar series, upper premolars inclined backward. From associated specimens in the American Museum of Natural History and the Carnegie Museum it appears that the skull of Merychyus is low, and limbs and feet long and slender.

\section{Ticholeptus Cope.}

Type Ticholeptus zygomaticus Cope. American Naturalist, XII., 1878, p. 129.
From the Ticholeptus (Deep River) beds of Smith River Valley, Montana. The type specimen consists of the greater portion of a skull with a mandible, preserved in the American Museum of Natural History. The skull is considerably crushed and still partly imbedded in the matrix. It is short and high, and the teeth moderately hypsodont. The premolars are crowded, but not reduced in size. There are small prelachrymal vacuities. Dr. Matthews and myself have each discovered, in Montana, skulls and parts of skeletons which we have assigned to this genus, but they are somewhat different, and one has longer limbs and feet than the other. It is very certain, as Dr. Matthews told me orally several years ago, that Ticholeptus is a valid genus, for the discovery of more complete specimens of Merychyus shows that the latter is a quite different animal.

\section{Merycochcerus Leidy.}

Type Merycochorus proprius Leidy. Proceedings Academy Natural Sciences, Philadelphia, 1858, p. 24.

The material consists of portions of a maxillary and a mandible with teeth from the Miocene red-grit bed near Fort Laramie, Wyoming, and is now in the Academy of Natural Sciences in Philadelphia. The skull, especially the posterior portion, is broad and low; the basicranial axis forms a considerable angle with the plane of the palate. The nasals are shortened, and the animal undoubtedly possessed a long nose, or proboscis. The teeth are hypsodont, the premolar is considerably shorter than the molar series, and the molars increase rapidly in length and height posteriorly. From this genus must be excluded the so-called Merycochorus laticeps Douglass and $M$. altiramus Douglass from Montana, which are still more specialized than the type of Merycochorus, the former of which has been assigned by the writer to a new genus which will shortly be published.

Carnegie Museum, October $15,1906$.
EARL S. Douglass. 